Bartosz Rakoczy

Uniwersytet Mikołaja Kopernika w Toruniu

\title{
PROCESOWY WYMIAR ZASADY ZRÓWNOWAŻONEGO ROZWOJU
}

\section{Wprowadzenie}

Zasada zrównoważonego rozwoju stanowi centrum współczesnych systemów prawa ochrony środowiska/prawa środowiska. Wokół tej koncepcji i zasady koncentrują się szczegółowe rozwiązania w poszczególnych systemach prawnych, poszukujących równowagi pomiędzy potrzebami ochrony środowiska a koniecznością oddziaływania na środowisko i koniecznością pozyskiwania zasobów środowiska.

Zasada zrównoważonego rozwoju koncentruje się więc na tym, aby znaleźć takie rozwiązania normatywne, które pozwolą pogodzić ze sobą wartości prawem chronione, pozostające ze sobą $\mathrm{w}$ konflikcie, $\mathrm{z}$ jednoczesnym uwzględnieniem potrzeb przyszłych pokoleń.

\section{Il. Zasada zrównoważonego rozwoju w systemie prawa polskiego}

W systemie prawa polskiego zasada zrównoważonego rozwoju została uregulowana w art. 5 Konstytucji Rzeczypospolitej Polskiej z dnia 2 kwietnia 1997 r. Przepis ten stanowi iż: „Rzeczpospolita Polska strzeże niepodległości i nienaruszalności swojego terytorium, zapewnia wolności i prawa człowieka i obywatela oraz bezpieczeństwo obywateli, strzeże dziedzictwa narodowego oraz zapewnia ochronę środowiska, kierując się zasadą zrównoważonego rozwoju".

Z kolei definicja pojęcia „Zrównoważony rozwój” zawarta jest w art. 3 pkt 50 ustawy z dnia 27 kwietnia 2001 roku Prawo ochrony środowiska. Zgodnie z tym przepisem: „Ilekroć w ustawie jest mowa o zrównoważonym rozwoju - rozumie się przez to taki rozwój społeczno-gospodarczy, w którym następuje proces integrowania działań politycznych, gospodarczych i społecznych, z zachowaniem równowagi 
przyrodniczej oraz trwałości podstawowych procesów przyrodniczych, w celu zagwarantowania możliwości zaspokajania podstawowych potrzeb poszczególnych społeczności lub obywateli zarówno współczesnego pokolenia, jak i przyszłych pokoleń".

W piśmiennictwie nie ma jednolitego stanowiska, co do charakteru prawnego tej zasady. Wskazuje się, że zasada zrównoważonego rozwoju jest zasadą ustrojową, przy czym podstawowym argumentem formułowanym w tej grupie poglądów jest umiejscowienie zasady zrównoważonego rozwoju w art. 5. ${ }^{1}$

Można również wyodrębnić grupę poglądów wskazujących, iż zasadą zrównoważonego rozwoju jest dyrektywa wykładni norm prawnych regulujących ochronę środowiska. Wreszcie zasada zrównoważonego rozwoju traktowana jest nie jako zasada ustrojowa, a jako zasada polityczna. W tym z kolei przypadku wiąże się art. 5 Konstytucji RP z art. 74 ust 1. W myśl tego drugiego przepisu: „Władze publiczne prowadzą politykę zapewniającą bezpieczeństwo ekologiczne współczesnemu i przyszłym pokoleniom".

\section{Zasada zrównoważonego rozwoju w orzecznictwie}

Rozbieżne stanowiska, co do charakteru prawnego zasady zrównoważonego rozwoju widać również w orzecznictwie. W wyroku z dnia 6 czerwca 2006 roku sygn. K23/05 Trybunał Konstytucyjny stwierdził, iż „Zaskarżone przepisy pozostają zatem w zgodzie z art. 5 i z art. 74 ust. 1 i 2 Konstytucji. Władze publiczne są bowiem przede wszystkim zobowiązane do „prowadzenia polityki zapewniającej bezpieczeństwo ekologiczne współczesnemu i przyszłym pokoleniom" (art. 74 ust. 1). Sformułowanie to ma charakter typowy dla określenia zadań (zasad polityki) państwa, nie rodzi natomiast bezpośrednio jakichkolwiek praw podmiotowych po stronie jednostki. Pojęcie „bezpieczeństwo ekologiczne” należy rozumieć jako uzyskanie takiego stanu środowiska, który pozwala na bezpieczne przebywanie w tym środowisku i umożliwia korzystanie $\mathrm{z}$ tego środowiska w sposób zapewniający rozwój człowieka. Ochrona środowiska jest jednym z elementów „bezpieczeństwa ekologicznego", ale zadania władz publicznych są szersze - obejmują też działania poprawiające aktualny stan środowiska i programujące jego dalszy rozwój. Podstawową metodą uzyskania tego celu jest - nakazane przez art. 5 Konstytucji - kierowanie się zasadą zrównoważonego rozwoju, co nawiązuje do ustaleń międzynarodowych, w szczególności konferencji w Rio de Janeiro w 1992 r. ${ }^{2}$ W ramach zasad zrównoważonego rozwoju mieści się nie tylko ochrona przyrody czy kształtowanie ładu przestrzennego, ale także należyta troska o rozwój społeczny i cywili- 
zacyjny, związany z koniecznością budowania stosownej infrastruktury, niezbędnej dla - uwzględniającego cywilizacyjne potrzeby - życia człowieka i poszczególnych wspólnot. Idea zrównoważonego rozwoju zawiera więc w sobie potrzebę uwzględnienia różnych wartości konstytucyjnych i stosownego ich wyważenia".

Natomiast w wyroku z dnia 25 marca 2009 r. II SA/Go 825/08 WSA w Gorzowie Wielkopolskim zauważył, iż: „Zasada zrównoważonego rozwoju pełni przede wszystkim rolę dyrektywy wykładni. A to wtedy gdy pojawiają się wątpliwości co do zakresu obowiązków, rodzaju obowiązków i sposobu ich realizacji należy posiłkować się zasadą zrównoważonego rozwoju. Pełni ona zatem rolę podobną do zasad współżycia społecznego czy społeczno-gospodarczego przeznaczenia w prawie cywilnym. W pierwszej kolejności do uwzględniania zasady zrównoważonego rozwoju obowiązany jest ustawodawca w procesie stanowienia prawa, ale z drugiej zasadę tę powinny mieć na uwadze organy stosujące prawo. Niekiedy bowiem stan faktyczny wymaga rozważenia i wyważenia rozwiązań korzystniejszych stosując zasadę zrównoważonego rozwoju".

\section{Charakter prawny zasady równoważonego rozwoju}

Dotychczas w piśmiennictwie nie podejmowano rozważań, czy zasada zrównoważonego rozwoju jest zasadą prawa materialnego, czy może zasadą procesową, jak również nie badano bliżej, kto w istocie jest adresatem tejże zasady. Tymczasem te dwie okoliczności mają bardzo istotne znaczenie dla praktycznego zastosowania zasady zrównoważonego rozwoju.

Odpowiedź na pytanie, kto jest adresatem zasady równoważonego rozwoju wcale nie jest rzeczą prostą. Nie można bowiem poprzestać na tradycyjnym ujęciu, iż adresatami są organy władzy publicznej, przedsiębiorcy, względnie jednostki itp. Adresatem zasady zrównoważonego rozwoju jest każdy podmiot, organ, jednostka, która ma jakikolwiek wpływ na urzeczywistnianie wartości pozostających ze sobą w konflikcie w sytuacji, gdy jedną z tych wartości jest ochrona środowiska. Zasada ta jest więc przede wszystkim skierowana do władz publicznych. To na władzach publicznych spoczywa obowiązek ochrony środowiska, co wynika nie tylko z art. 5 Konstytucji RP, ale również z art. 74 ust. 2 Konstytucji RP.

Przepis ten stanowi iż: „Ochrona środowiska jest obowiązkiem władz publicznych".

Uwzględniając podział władzy publicznej na władzę wykonawczą, władzę ustawodawczą oraz władzę sądowniczą należy wskazać, że zasada zrównoważonego rozwoju jest zaadresowana zarówno do organów stanowiących prawo, jak i organów je stosujących. Ponieważ prawo ochrony środowiska jest stosowane przede wszystkim przez organy administracji publicznej, można przyjąć, że zasada ta jest adresowana w głównej mierze do władzy prawodawczej i władzy wykonawczej. 
Wynika to z tego, że urzeczywistnianie skonfliktowanych wartości może następować zarówno na płaszczyźnie stanowienia prawa, jak i na płaszczyźnie stosowania prawa. Konflikt ten może być rozwiązywany arbitralną decyzją prawodawcy. Jednak prawodawca pozostaje na płaszczyźnie rozwiązań generalnych i abstrakcyjnych. Może on zatem rozwiązywać te konflikty pomiędzy abstrakcyjnymi wartościami, za którymi nie stoją konkretne stany faktyczne. W tej sytuacji zasada zrównoważonego rozwoju wprawdzie będzie pełniła swoją funkcję instrumentu rozwiązywania konfliktów, jednak nie w pełnym zakresie, gdyż konflikty te będą ciągle pozostawały na poziomie generalnym i abstrakcyjnym. Trafnie podnosi J. Zimmermann, iż ,lista wartości ujmowanych w prawie administracyjnym jest niezwykle szeroka, a ułożenie ich w jakiejś hierarchii jest w istocie niewykonanlne. [...] Okazuje się jednak, że podstawowe wartości praktycznie zawsze występują w różnych kontekstach znacznie bogatszych w treść i przy każdym działaniu administracja publiczna ma obowiązek brać pod uwagę cały system wartości. Jeśli tak, to w ten sam sposób powinien postępować ustawodawca i każdy inny podmiot ustanawiający akty normatywne". ${ }^{3}$

Zatem w najpełniejszy sposób zasada zrównoważonego rozwoju urzeczywistni się dopiero na etapie stosowania prawa. Tego zagadnienia dotyczy to opracowanie. Stosowanie prawa jest definiowane w teorii prawa jako ,władcza działalność organów państwa polegająca na wydawaniu decyzji indywidualno-konkretnych (akty stosowania prawa) na podstawie norm prawnych (aktów tworzenia prawa). [...] Działalnością władczą organów państwowych jest także tworzenie prawa. Przypomnijmy więc już po raz kolejny, że różnica między tymi działaniami polega na tym, iż w przypadku tworzenia prawa powstają normy ogólne (generalno-abstrakcyjne), natomiast rezultatem procesów stosowania prawa są normy indywidualno-konkretne". 4

Interesujący pogląd co do pojmowania stosowania prawa prezentują J. Nowacki i Z. Tobor. Podkreślają Oni, iż ,ze stosowaniem prawa mamy do czynienia wtedy, gdy jakiś podmiot na podstawie norm generalnych i abstrakcyjnych określa skutki prawne jakiegoś faktu, wydając decyzję indywidualną w rozstrzyganej sprawie". 5 Jednocześnie Autorzy ci słusznie wskazują na wątpliwości co do analizowanego pojęcia dotyczące tego, iż podmiotem stosującym prawo nie jest jedynie organ wyposażony w kompetencje władcze, ale także $\mathrm{i}$ inne podmioty prawa. J. Nowacki i Z. Tobor podnoszą też, że bardziej adekwatnym sformułowaniem, zamiast stosowanie prawa jest sformułowanie konkretyzacja, urzeczywistnianie, czy nawet odnajdywanie prawa. ${ }^{6}$

Cechą charakterystyczną stosowania prawa jest więc to, że następuje ono w prawem określony sposób, na podstawie przepisów prawa formalnego. Istotną cechą stosowania prawa jest również jego ścisły związek z określonymi stanami faktycz-

\footnotetext{
J. Zimmermann, Aksjomaty prawa administracyjnego, Warszawa 2013, s. 100-101.

L. Morawski, Wstęp do prawoznawstwa, wyd. XII, Toruń 2011, s. 125.

J. Nowacki, Z. Tobor, Wstęp do prawoznawstwa, wyd. 3, Warszawa 2012, s. 176.

Ibidem, s. 177.
} 
nymi, dlatego też w przepisach prawa formalnego istotną rolę odgrywają te normy, które regulują sposób ustalania stanu faktycznego. Choć podążając tokiem rozumowania J. Nowackiego i Z. Tobora należałoby stwierdzić, że podmiotem stosującym prawo może być również podmiot inny niż organ władzy publicznej.

Powiązanie stosowania prawa ze stanem faktycznym powoduje przejście z płaszczyzny generalnej i abstrakcyjnej na płaszczyznę konkretnych sytuacji i konkretnych zjawisk. Organ stosujący prawo nie prowadzi i nie może już prowadzić generalnych i abstrakcyjnych rozważań, którą ze skonfliktowanych wartości wybrać, ale prowadzi rozważania dotyczące konkretnych elementów.

Formalnoprawny wymiar zasady zrównoważonego rozwoju nakłada na organ stosujący prawo konieczność uwzględnienia dwóch elementów. Po pierwsze organ stosujący zasadę zrównoważonego rozwoju powinien dążyć do takiego rozstrzygnięcia sprawy, aby w jak najpełniejszym zakresie urzeczywistniać skonfliktowane wartości. Przejawia się to w tym, że organowi stosującemu prawo nie wolno opowiedzieć się za jedną wartością przeciwko drugiej, nawet jeśli jest to organ ochrony środowiska. Organowi nie wolno również na samym początku postępowania decydować o tym, którą wartość będzie chronił kosztem innej wartości, a której nie będzie obejmował ochroną.

Naruszenie tej reguły doprowadzi do sytuacji, iż organ będzie promował jedną z wartości kosztem drugiej i prawdopodobnie nie uniknie nadmiernego ograniczenia dyskryminowanej wartości.

Urzeczywistnianie obu skonfliktowanych wartości wymaga od organu stosującego prawo w pierwszej kolejności uświadomienia sobie istnienia takiego konfliktu.

Można z powodzeniem wręcz przyjąć domniemanie istnienia konfliktu wartości w sprawach dotyczących ochrony środowiska. Organ może więc rozpoczynając rozpoznawanie sprawy administracyjnej zakładać, że taki konflikt istnieje. Najlepszym dowodem na zasadność konstruowania takiego domniemania jest chociażby dopuszczenie do udziału w określonego rodzaju postępowaniach organizacji ekologicznych, które działają w tychże postępowaniach na prawach strony. Słusznie zauważa M. Micińska, iż „Ważną przesłanką [udziału społeczeństwa w ochronie środowiska - przyp. B.R.], wymuszającą regulacje służące zapewnieniu udziału społeczeństwa jest zapobieganie konfliktom społecznym powstałym na tle ekologicznym, a w razie ich zaistnienia - łagodzenie i znajdowanie dla nich optymalnego rozwiązania”.?

Organ, tym bardziej organ ochrony środowiska powinien więc a priori zakładać istnienie konfliktu w sprawach, w których w grę wchodzi ochrona środowiska. Uświadamiając sobie istnienie takiego konfliktu organ administracji publicznej powinien dążyć do jego dokładnego zidentyfikowania. Powinien on ustalić między konkretnie jakimi elementami ten konflikt występuje. Ustalenia takie poczyni on 
na podstawie zgromadzonego w sprawie materiału dowodowego, w tym także podania (wniosku), oczywiście jeśli postępowanie jest wszczynane na wniosek. W mojej ocenie identyfikacja konkretnych skonfliktowanych ze sobą elementów jest kluczowym punktem stosowania prawa. Dalsze bowiem czynności procesowe organu administracji publicznej, a w szczególności rozstrzygnięcie kończące postępowanie w danej instancji będą zdeterminowane prawidłowością lub wadliwością poczynionych przez organ administracji publicznej ustaleń.

Jest to też ten moment całego procesu stosowania prawa, który sprawa, iż zasada zrównoważonego rozwoju nabiera swojego wymiaru prawnoprocesowego. Służy ona bowiem właściwemu dalszemu procedowaniu przez organ administracji publicznej.

W tym miejscu można postawić pytanie, czy zasada zrównoważonego rozwoju jest zasadą postępowania administracyjnego? Zasadność takiego pytania jest zdeterminowana poczynionymi wyżej uwagami, iż zasada zrównoważonego rozwoju ma służyć organowi administracji publicznej do właściwego rozstrzygnięcia sprawy, której przedmiotem jest środowisko i potrzeba jego ochrony.

S. Rozmaryn poczynił uwagę, iż zasady ogólne kodeksu postępowania administracyjnego są to zasady ogólne w tym sensie, że chodzi tu z reguły o przepisy wyjęte niejako przed nawias, a więc wspólne dla całości postępowania administracyjnego. ${ }^{8}$

Istotne znaczenie ma po pierwsze to, czy zasada zrównoważonego rozwoju jest wyłączona niejako przed nawias, a po drugie czy jest to zasada wspólna dla całości postępowania.

W obu przypadkach należy udzielić odpowiedzi negatywnej. Przesłanka wyłączenia przed nawias, którą sformułował S. Rozmaryn zakłada wyodrębnienie takiej zasady nie tylko w aspekcie merytorycznym, ale także w aspekcie formalnym. W tym drugim przypadku chodzi o wyodrębnienie tej zasady w określonej części aktu prawnego. E. Bojanowski zauważa, iż: „Przez zasady ogólne można też rozumieć zasady przedstawione w postaci przepisów prawnych, zgrupowanych w odrębnym rozdziale Kodeksu postępowania administracyjnego. W tym przypadku mamy do czynienia z zasadami, które zostały wybrane przez ustawodawcę". ${ }^{9} \mathrm{O}$ ile można przyjąć, iż zasada zrównoważonego rozwoju jest wyłączona przed nawias, o tyle nie jest ona ujęta w odrębnej jednostce redakcyjnej wyższej tekstu prawnego. Zasada zrównoważonego rozwoju pełnić powinna funkcję interdyscyplinarną. W takim też kontekście ujęta jest ona w art. 5 Konstytucji RP. Odnosi się bowiem nie tylko do wymiaru środowiskowego, ale do wszystkich wartości wymienionych w tym przepisie. Ustawodawca konstytucyjny nadaje jej szerszy wymiar, a nawet uniwersalny. ${ }^{10}$

8

9

10
S. Rozmaryn, O zasadach ogólnych Kodeksu postępowania administracyjnego, PiP 1961, z. 12, s. 636.

E. Bojanowski, (w:) J. Lang (red.), Postępowanie administracyjne i postępowanie przed sądami administracyjnymi, wyd. 4, Warszawa 2010, s. 24.

Problem wymaga jednak głębszej analizy, gdyż ustawodawca zwykły wydaje się utożsamiać zasadę zrównoważonego rozwoju z ochroną środowiska, czego dowodem jest zdefiniowanie pojęcia zrównoważony rozwój właśnie w ustawie z dnia 27 kwietnia 2001 r. Prawo ochrony środowiska. 
Natomiast uwzględniając drugą przesłankę wskazywaną przez S. Rozmaryna zasady zrównoważonego rozwoju nie można uznać za wspólną dla całości postępowania administracyjnego.

$\mathrm{W}$ piśmiennictwie z zakresu prawa administracyjnego wskazuje się na istnienie postępowania administracyjnego ogólnego i postępowań szczególnych. Wyraźnie zarysowuje się tendencja do wyodrębniania coraz to większej liczby postępowań szczególnych. Uzasadnia się to coraz większą specjalizacją poszczególnych postępowań i idącą za tym coraz większą specyfikacją tychże. J. Borkowski, analizując pojęcie przedmiotu postępowania administracyjnego słusznie podniósł, iż: „Dziedziny spraw, które można kwalifikować jako administracyjne, są zmienne, bo zależą od wielu okoliczności, wśród których niepoślednią rolę odgrywają względy koniunkturalne. [...] W szeregu dziedzin życia społecznego i gospodarczego zakres spraw poddanych orzecznictwu organów administracyjnych jest wyznaczany realizacją międzynarodowych zobowiązań państwa płynących z konwencji i umów. [...] Prawo unijne wpływa w istotny sposób na zakres orzecznictwa administracyjnego w sprawach ochrony konkurencji i konsumentów, utrzymywania standardów produkcji i obrotu środków żywności czy dopuszczania do obrotu farmaceutyków". ${ }^{11}$ Bez wątpienia do kategorii przykładów wskazywanych przez J. Borkowskiego należy również i ochrona środowiska. W piśmiennictwie wręcz wskazuje się na istnienie procesowego prawa ochrony środowiska. ${ }^{12}$

Niezależnie jednak od istnienia postępowań szczególnych, w każdym postępowaniu obowiązują zasady określone w k.p.a. W postępowaniach szczególnych można zauważyć wyodrębnianie dodatkowych zasad. W tym też kontekście zasada zrównoważonego rozwoju jest charakterystyczna dla postępowań administracyjnych z zakresu ochrony środowiska. ${ }^{13}$ Jest to konsekwencją wskazywanej wyżej tendencji w ustawodawstwie zwykłym utożsamiania zasady zrównoważonego rozwoju z ochroną środowiska.

Stąd też zasada zrównoważonego rozwoju znajduje swoje zastosowanie w praktyce jedynie w tych sprawach, które dotyczą ochrony środowiska. Nie jest więc zasadą ogólną.

Z powyższych względów zasada zrównoważonego rozwoju nie może być traktowana jako zasada k.p.a. Konsekwentnie nie można więc mówić o tym, że zasada zrównoważonego rozwoju jest zasadą procesową. Natomiast uzasadnione jest rozważanie procesowego charakteru tejże zasady.

Po ustaleniu, między jakimi konkretnymi wartościami dochodzi do konfliktu organ administracji publicznej powinien zmierzać do takiego rozstrzygnięcia sprawy

\footnotetext{
11 J. Borkowski, (w:) R. Hauser, Z. Niewiadomski, A. Wróbel (red.), System Prawa Administracyjnego, t. IX - Prawo procesowe, Warszawa 2010, s. 132-133.

12 Por. B. Rakoczy, Le droit procédural de l'environnement, (w:) J. Niczyporuk (red.), Les problěmes théoriques de la science administrative, Bruxelles-Paris 2012, s. 291-298.

13 Por. B. Rakoczy, Ciężar dowodu w polskim prawie ochrony środowiska, Warszawa 2010.
} 
administracyjnej, które pozwoli w jak najpełniejszym stopniu urzeczywistnić i objąć ochroną skonfliktowane wartości. Na tym etapie stosowania prawa powinien on odrzucić skrajne postawy, zmierzające do promowania jednej wartości kosztem drugiej. Organ winien więc wyważać, a użycie tego sformułowania w uzasadnieniu wyżej cytowanego orzeczenia TK jest w pełni uzasadnione.

Obejmując jak najpełniejszą ochroną skonfliktowanych ze sobą wartości organ administracji publicznej powinien szukać takiego rozwiązania, które promowanie jednego elementu w określonym kontekście będzie jednocześnie równoważone ochroną drugiego elementu w innym kontekście. Wyważanie wartości należy rozumieć bowiem wąsko i szeroko.

Wyważanie wartości w szerokim tego słowa znaczeniu nastąpi, jeśli organ będzie odnosił się do całości tychże wartości. W takim wypadku będzie rozstrzygał w systemie zero-jedynkowym, co w praktyce będzie trudne do urzeczywistnienia. Właściwsze będzie węższe podejście do kwestii wyważania, polegające na tym, że organ będzie uwzględniał części składowe tychże wartości, a nie owe wartości jako całości. W tym wypadku będzie mógł stosować system zero-jedynkowy w mniejszych obszarach. Będzie mógł zatem w tych mniejszych obszarach opowiadać się za jedną z tych wartości, gdyż zrównoważy drugą wartość w innym, mniejszym obszarze. W ten sposób organ ochrony środowiska zachowa też niezbędną elastyczność. ${ }^{14}$

Może jednak dojść do takiej sytuacji procesowej, gdy urzeczywistnianie skonfliktowanych ze sobą wartości jest niemożliwe. W takiej sytuacji zasada zrównoważonego rozwoju, w swoim procesowym wymiarze, nakazuje organowi stosującemu prawo opowiedzieć się za jedną z wartości, nawet jeśli nastąpi to kosztem drugiej. Jednak ewentualne rozstrzygnięcie konfliktu poprzez opowiedzenie się przez organ stosujący prawo za jedną z wartości jest uzależniony od obiektywnego braku możliwości ochrony skonfliktowanych ze sobą wartości. Brak możliwości urzeczywistniania skonfliktowanych wartości nie może mieć charakteru subiektywnego.

Opowiadając się za jedną z wartości organ stosujący prawo musi jednak podać motywy takiego rozstrzygnięcia. Powinny one przede wszystkim zawierać identyfikację konfliktu, poprzez wskazanie konkretnych elementów, jakie w tym konflikcie uczestniczą. Następnie organ winien wskazać, dlaczego z obiektywnego punktu widzenia nie ma możliwości urzeczywistniania skonfliktowanych wartości. Dopiero w końcowej fazie rozumowania organ winien uzasadnić opowiedzenie się za jedną z wartości, kosztem drugiej.

Zamiast mówić o konflikcie pomiędzy prawem własności a ochroną środowiska, nawet jeśli ma on już konkretny wymiar i umocowanie w stanie faktycznym, lepiej jest mówić np. o ograniczeniu niektórych, czy nawet jednego uprawnienia właściciela, które ze względu na określony element środowiska ulegnie ograniczeniu. Z kolei organ też nie może urzeczywistniać ochrony środowiska jako jednej holistycznie rozumianej wartości, ale powinien skupić się na jego konkretnych elementach, które mogą ulec naruszeniu w wyniku ochrony prawa własności. Dobrym przykładem takiego wyważenia, choć na płaszczyźnie legislacyjnej, są przepisy ustawy o ochronie przyrody o usuwaniu drzew. Por. K. Gruszecki, Zezwolenie na usunięcie drzew i krzewów, wyd. 2, Wrocław 2011; B. Rakoczy, Usuwanie drzew i krzewów, Warszawa 2013. 
W takim też kontekście zasada zrównoważonego rozwoju jest w pełni urzeczywistniana i pełni istotną rolę procesową, choć zasadą procesową nie jest.

\section{Podsumowanie}

Reasumując należy podkreślić, że choć zasada zrównoważonego rozwoju nie jest zasadą procesową, to jednak odgrywa istotną rolę w stosowaniu prawa, przede wszystkim prawa ochrony środowiska. Stąd też można mówić o jej procesowym wymiarze. Zasada ta jest jednak znacznie szersza i obejmuje nie tylko problematykę procesowoprawną, ale także kwestie materialnoprawne. Rozciąga się ona również na wymiar legislacyjny.

Zasada zrównoważonego rozwoju wykracza także poza obszar materii normatywnej definiowany jako prawo ochrony środowiska.

Procesowy wymiar zasady zrównoważonego rozwoju objawia się jednak przede wszystkim właśnie w sprawach z zakresu ochrony środowiska, w których można przyjąć domniemanie istnienia konfliktu pomiędzy ochroną środowiska z jednej strony a innymi wartościami z drugiej.

Zasada zrównoważonego rozwoju wymaga od organu stosującego prawo najpierw uświadomienia sobie takiego konfliktu, a następnie jego identyfikacji i konkretyzacji. W dalszej kolejności organ winien dążyć do takiego rozstrzygnięcia, które pozwoliłoby urzeczywistnić skonfliktowane wartości. Dopiero w przypadku obiektywnej niemożności urzeczywistniania obu wartości organ ma obowiązek opowiedzieć się za jedną z nich i uzasadnić swoje rozstrzygnięcie. 


\section{PROCEDURAL ASPECTS - THE PRINCIPLE OF SUSTAINABLE DEVELOPMENT}

Although the principle of sustainable development is not a procedural rule it does play an important role in the application of law, and mostly environmental protection law. Thus it could be given a procedural dimension.

The principle of sustainable development requires the authority applying legislation first to become aware of a conflict and then to identify and specify its nature. Further, the authority should attempt to find a solution to enable accomplishment of the conflicting values. Only when, from an objective point of view, it is impossible to accomplish both values, the authority is obliged to advocate one of such values and to state the reasons for that particular decision.

Keywords: principle of sustainable development, procedural rule, application of law 